OPEN ACCESS

Edited by:

Ricardo D. Coletta,

Campinas State University, Brazil

Reviewed by:

Rogelio González-González, Juárez University of the State of

Durango, Mexico

Mariana Villarroel-Dorrego,

Central University of

Venezuela, Venezuela

*Correspondence:

Sven E. Niklander

sven.niklander@unab.c

Specialty section:

This article was submitted to

Oral Cancers,

a section of the journal

Frontiers in Oral Health

Received: 15 December 2020

Accepted: 13 January 2021

Published: 22 February 2021

Citation:

Niklander SE (2021) Inflammatory Mediators in Oral Cancer: Pathogenic Mechanisms and Diagnostic Potential.

Front. Oral. Health 2:642238.

doi: 10.3389/froh.2021.642238

\section{Inflammatory Mediators in Oral Cancer: Pathogenic Mechanisms and Diagnostic Potential}

\author{
Sven E. Niklander* \\ Unidad de Patologia y Medicina Oral, Facultad de Odontologia, Universidad Andres Bello, Viña del Mar, Chile
}

Approximately $15 \%$ of cancers are attributable to the inflammatory process, and growing evidence supports an association between oral squamous cell carcinoma (OSCC) and chronic inflammation. Different oral inflammatory conditions, such as oral lichen planus (OLP), submucous fibrosis, and oral discoid lupus, are all predisposing for the development of OSCC. The microenvironment of these conditions contains various transcription factors and inflammatory mediators with the ability to induce proliferation, epithelial-to-mesenchymal transition (EMT), and invasion of genetically predisposed lesions, thereby promoting tumor development. In this review, we will focus on the main inflammatory molecules and transcription factors activated in OSCC, with emphasis on their translational potential.

Keywords: oral cancer, inflammation, oral carcinogenesis, biomarker, OPMD

\section{INTRODUCTION}

The links between cancer and chronic inflammation are well-established. In this process, pro-inflammatory mediators act by stimulating inflammation to either abrogate tumor progression or facilitate tumor growth and metastasis $[1,2]$. Approximately $15 \%$ of cancers are attributable to the inflammatory process [3]. Such cancers include lung, pancreatic, esophageal, bladder, gastric, cervical, colorectal, and prostate [4]. During the oral malignant transformation process [from non-dysplastic hyperkeratosis, through oral dysplasia to the development of oral squamous cell carcinoma (OSCC)], there is a progressive increase of the inflammatory infiltrate (quality and density) [5], and growing evidence supports an association between OSCC and chronic inflammation [6, 7]. Different oral inflammatory conditions, such as OLP, submucous fibrosis, and oral discoid lupus, are all predisposing for the development of OSCC [8]. The microenvironment of these conditions contains activated cytokines and chemokines, prostaglandins, reactive oxygen species, and various transcription factors. Some of these mediators have the ability to induce proliferation, epithelial-to-mesenchymal transition (EMT), and invasion [9] of genetically predisposed lesions (with mutations in tumor-suppressor genes and/or oncogenes), thereby promoting tumor development. In established OSCC, chronic inflammation is also a common feature, being involved in tumor progression, invasion, and metastasis $[5,6,10]$. Thus, many studies have assessed the utility of different inflammatory molecules as prognostic biomarkers and treatment targets for OSCC.

The aim of this review is to outline the main inflammatory molecules and transcription factors activated in OSCC, with special focus on their translational potential. 


\section{INFLAMMATORY MEDIATORS INVOLVED IN ORAL CARCINOGENESIS}

There are different inflammatory mediators reported to have a role in the development and progression of OSCC (Table 1). In this review, we will focus on the most commonly investigated.

\section{NF-kB}

Nuclear factor kappa-beta (NF-kB) is a key inflammatory transcription factor frequently expressed in tumors that regulates the expression of a variety of genes involved in inflammation, proliferation, tumorigenesis, and cell survival [47-49]. NF-кB is canonically activated by tumor necrosis factor alpha (TNF$\alpha$ ), interleukin (IL)-1, and lipopolysaccharide (LPS) [48], and when activated, it enhances the expression of different cytokines, including IL-1, IL-6, and IL-8 [50]. Its aberrant expression is linked to carcinogenesis [51] and EMT induction [52] and is associated with worse survival in solid cancers [53]. In OSCC, NF- $\kappa \mathrm{B}$ is constitutively activated and is associated with the upregulation of different inflammatory genes, including $I L-6$, IL-8, CCL5, and CXCL10 [6], and is considered a major factor responsible for the inflammatory infiltrate observed in the tumor microenvironment (TME) [54]. NF- $\mathrm{KB}$ has an important role in the malignant phenotype of oral cancers, as it participates in the modulation of bone invasion [48]; enhances angiogenesis [55], invasion [40,56], and metastasis [40, 41]; and induces EMT [52]. The EMT process is a crucial step for the development of OSCC metastasis [57]. It involves the repression of E-cadherin (an important epithelial adhesion molecule) via Snail expression, which depends on NF- $\mathrm{kB}$ activation via AKT [52]. IL-8 and EGF are able to induce EMT via NF- $\mathrm{KB}$ activation, and IL-8- and EGF-induced EMT can be reversed by blocking AKT or NF$\kappa \mathrm{B}[58,59]$. NF- $\mathrm{KB}$ importance during OSCC development is well-exemplified by its inactivation, as this inhibits cell survival and growth; expressions of IL- $1 \alpha$, IL-6, and IL-8 [60]; and metastases [41]. Because of this, NF-кB inhibition has been proposed as a possible treatment for head and neck squamous cell carcinoma (HNSCC).

\section{AP-1 Pathway}

Activator protein 1 (AP-1) is a transcription factor complex composed of either homodimers of Jun protein or heterodimers of Jun and Fos proteins [61] that orchestrates the expression of different genes involved in inflammation, embryonic development, lymphoid proliferation, oncogenesis, and apoptosis [62] and is reported to be essential for DNA synthesis [63]. AP-1 activation seems to be of clinical significance in cancer, as high expression levels have been associated with drug resistance [64]. AP-1 is activated during oral keratinocyte carcinogenesis [37], and its expression increases with oral tumor

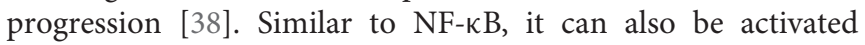
by IL-1 [65], which induces IL-8 secretion and promotes the cell survival and growth of HNSCC cells [39]. A recent study suggested that AP- 1 induces bcl- 2 expression (a proto-oncogene related to apoptosis suppression implicated in resistance to chemoradiation therapy in OSCC) in recurrent chemo- and radioresistant oral tumors [38], which suggests that targeting
TABLE 1 | Inflammatory pathways and mediators reported to have a role in oral carcinogenesis.

\begin{tabular}{|c|c|}
\hline Pro-inflammatory cytokines & References \\
\hline $\mathrm{IL}-1$ & {$[7,9,11,12]$} \\
\hline IL-1R1 & [13] \\
\hline IL-6 & {$[6,11,14]$} \\
\hline IL-8 & {$[6,11,14,15]$} \\
\hline TNF- $\alpha$ & {$[5,11,16]$} \\
\hline TGF- $\beta$ & {$[17-19]$} \\
\hline \multicolumn{2}{|l|}{ Immunosuppresive Cytokines } \\
\hline IL-1RA & {$[20,21]$} \\
\hline IL-2 & [22] \\
\hline $\mathrm{IL}-4$ & {$[22,23]$} \\
\hline $\mathrm{IL}-10$ & [24-26] \\
\hline $\mathrm{IL}-12$ & [27] \\
\hline $\mathrm{IL}-13$ & [24] \\
\hline $\mathrm{IFN}-\gamma$ & {$[14,28]$} \\
\hline \multicolumn{2}{|l|}{ Chemokines } \\
\hline $\mathrm{CCL}$ & [29] \\
\hline CXCL1 & [30] \\
\hline CXCL2 & {$[29,31]$} \\
\hline CCL4 & [32] \\
\hline CCL7 & [33] \\
\hline CXCL3 & [29] \\
\hline CXCL10 & [34] \\
\hline CXCL12 & [31] \\
\hline CXCR1 & {$[35,36]$} \\
\hline CXCR2 & [36] \\
\hline \multicolumn{2}{|l|}{ Transcription factros } \\
\hline AP-1 & {$[37-39]$} \\
\hline NF-kB & {$[6,40-42]$} \\
\hline \multicolumn{2}{|l|}{ Enzymes } \\
\hline cox2 & [43-45] \\
\hline \multicolumn{2}{|l|}{ Prostanoids } \\
\hline PGE2 & [46] \\
\hline
\end{tabular}

the AP-1 pathway might contribute to overcome resistance to chemoradiation therapy in OSCC. As AP-1 can be activated by IL-1, targeting IL-1 could be beneficial for oral cancer treatment, as this could reduce the activation of NF- $\kappa \mathrm{B}$ and AP- 1 pathways with subsequent reduction of bcl-2, but this hypothesis needs to be corroborated.

\section{TNF- $\alpha$}

TNF- $\alpha$ is a multifunctional cytokine identified as an important mediator of cancer development [66], as well as induces EMT [67] and enhances tumor angiogenesis [68] and invasion [56]. Therefore, it is considered an important regulator of proliferation, invasion, and metastasis of many cancers [69]. TNF- $\alpha$ is expressed in some oral potentially malignant disorders (OPMDs), such as OLP [70], and is endogenously expressed in oral carcinomas [71]. In OSCC, TNF- $\alpha$ promotes a proinvasive and pro-inflammatory phenotype in a paracrine manner 
$[5,16]$ by upregulating genes that are associated with neutrophil recruitment, invadopodia, and invasion. The upregulation of these genes was also associated with reductions in both the overall survival and disease-free survival of patients with OSCC [5]. Elevated TNF- $\alpha$ receptor-1 (TNFR-1) signaling has also been associated with metastasis of OSCC [41, 72], attributable to the ability of TNF- $\alpha$ to stimulate the invasion of OSCC cells by enhancing matrix metalloproteinase (MMP)-2 and MMP-9 production $[41,56]$, which is regulated by the NF- $\mathrm{B}, \mathrm{AKT}$, and PI3K signaling pathways $[5,41,72]$. It has been demonstrated that MMPs play critical roles in OSCC, as elevated expression of MMPs is associated with increased OSCC invasion, metastasis, and poor prognosis [73-75]. MMPs are also reported to have a prominent role in the EMT process [76], as MMP-2, MMP9, and MMP-7 are able to enhance EMT [77-79]. NF-кB is an important regulator of MMPs [80], and TNF- $\alpha$ can activate NF$\kappa \mathrm{B}$ via TNFR1, which results in enhanced MMP secretion [81]. TNF- $\alpha$ is also able to induce EMT via p38 MAPK activation [82], and TNF- $\alpha$-induced EMT has been related to the induction of cancer stem cells (CSCs) [67]. The presence of CSCs in OSCC is of importance as this has been linked to therapy resistance and worst prognosis. In OSCC, the expression of CD44 (a wellknown CSC marker) has been associated with increased cell invasion, cell migration, and therapy resistance via a mechanism that includes the activation of PI3K/Akt/GSK3 $\beta$ and Raf-MEKERK signaling networks [83], and silencing CD47 (a molecule involved in the generation of CSCs in OSCC) has shown to reduce EMT and the presence of CSCs [84]. The activation of the PI3K/Akt/GSK3 $\beta$ signaling pathway has also been associated with increased proliferation, invasion [85], the development of EMT, and distant metastasis [86].

Due to all the beneficial effects of TNF- $\alpha$ during cancer development, targeting TNF- $\alpha$ might be a useful strategy for OSCC treatment. In vitro experiments have shown anti-TNF- $\alpha$ therapy to reduce growth and metastasis of OSCC cells [87], but this needs to be investigated further before it can be translated into the clinic.

\section{IL-6 and IL-8}

Both IL-6 and IL-8 are considered "oncogenic cytokines," as they are able to cause EMT [88], stimulate angiogenesis and tumor growth $[89,90]$, disrupt cell-cell communication, impede macrophage function, and promote epithelial and endothelial cell migration and invasion [91]. IL-6 and IL-8 levels are elevated in patients with OPMDs and OSCCs [6, 14, 92, 93], which is likely to be a consequence of aberrant NF- $\kappa$ B activation [94]. IL- 6 and IL- 8 can be produced by malignant oral keratinocytes themselves, or by other cells of the TME, such as tumorassociated macrophages (TAMs). TAMs are an important source of both of these cytokines, and thus many attempts have been done to target TAMs to restrict their secretion [95]. IL-8 is reported to act as an autocrine growth factor in HNSCC and other cancers [15] and has been proposed as a potential mediator of the development of OSCC. It is constitutively expressed in malignant oral keratinocytes, and its inhibition decreases viability, proliferation [6], and invasion of OSCC cells [16] and enhances the proliferation, angiogenesis, and survival rate of cancer cells [96]. Similarly, IL-6 overexpression in patients with HNSCC is associated with poor prognosis, probably by enabling an immunosuppressive TME by increasing the presence of myeloid-derived suppressor cells and PDL-1 expression, and is considered a significant predictor of treatment outcome [97]. In OSCC, the expressions of IL- 6 and IL- 8 are associated with a more invasive mode of growth [11].

\section{IL-1 Family Members}

IL-1 is the prototype of a pro-inflammatory cytokine and includes IL- $1 \alpha$ and IL- $1 \beta$. IL- $1 \alpha$ and IL- $1 \beta$ are both constitutively expressed in OSCC $[9,12,98,99]$, can be found in the saliva of patients with OSCC $[100,101]$, and have been reported to have important functions in OSCC carcinogenesis and tumor progression $[7,10]$.

IL-1 $\alpha$ expressed by OSCC promotes autocrine activation of NF- $\kappa \mathrm{B}$ and AP-1 and upregulates the expression of IL-8 [39] and IL-6 [98]. OSCC cells produce IL-1 $\alpha$ [12], which induces the proliferation and cytokine secretion by cancer-associated fibroblasts (CAFs) (CCL7, CXCL1, and IL-8), promoting tumor progression [33]. IL-1 $\alpha$ seems to be important for the development of distant metastases, as IL- $1 \alpha$ is highly expressed in metastatic HNSCC tumors compared to non-metastatic HNSCC tumors. This is probably achieved by the capability of IL- $1 \alpha$ to induce transmigration of tumor cells across the endothelium and to enhance the expression of metastatic genes, such as MMP-9, $P G E 2, V E G F$, and $I L-8$ [10]. It has also been reported that IL- $1 \alpha$ can act as an oncoprotein by itself, as intranuclear IL- $1 \alpha$ has been shown to induce malignant transformation of cells from the bone marrow and perivascular area [102].

IL- $1 \beta$ increases the levels of IL- 6 and IL- 8 expressed by OD and OSCC cells and promotes the invasiveness of OSCC by inducing EMT [9]. IL-1 $\beta$ has also been identified as a key node gene in the TME of OSCC in vivo [7]. The expression of precursor IL-1 $\beta$ mRNA is correlated with the presence of malignant changes (from normal, to mild, through severe dysplasia to OSCC) [9], and elevated IL-1 $\beta$ expression has been related to lymph node metastasis of OSCC [103]. IL-1 produced by HNSCC can also stimulate the production of different cytokines by CAFs and normal fibroblasts, such as CCL-7, CXCL1, IL-8, and CCL-5 $[33,104]$. These findings strongly suggest a possible role of IL-1 $\beta$ in the oral carcinogenesis process, which is supported by the fact that IL- $1 \beta$ silencing can reduce tumor size in vivo [7].

The IL-1 agonist receptor, IL-1R1, is also overexpressed in OSCCs and, together with IL-1 $\beta$, was shown to promote cancer growth and metastasis by upregulating CXCR4, which could be reversed by inhibiting IL-1R1 by overexpressing the interleukin 1 receptor antagonist (IL-1RA) [13]. Interestingly, IL-1RA has been reported to be downregulated in OD and in OSCC [20] and is reported to regulate IL-1-induced secretion of IL- 6 and IL- 8 by inhibiting the $38 \mathrm{MAPK}$ and NF- $\kappa \mathrm{B}$ pathways $[50,105]$.

\section{COX-2}

Cyclooxygenase (COX)-2, an inflammation-induced enzyme that converts arachidonic acid into prostaglandins [e.g., prostaglandin E2 (PGE2)], is frequently expressed in many types of cancers. COX-2 is able to induce CSC-like activity and to promote 
angiogenesis, proliferation, apoptotic resistance, inflammation, invasion, and metastasis of cancer cells [106]. Importantly, COX2 inhibition has been shown to reverse cancer progression [107, 108]. COX-2 is induced by a variety of molecules, including IL-1 [109], epithelial growth factor (EGF) [110], transforming growth factor-beta (TGF- $\beta$ ) $[111,112]$, and TNF- $\alpha$. COX-2 expression is induced early in the process of oral carcinogenesis [43]. Its level is associated with the degree of dysplasia [44], is overexpressed in OSCC $[113,114]$, and is correlated with advanced tumor stage, high risk of distant metastasis [115], and worse prognosis in patients with OSCC [116]. In oral cancer, COX-2 is of importance for maintaining a chronic inflammatory state [117], influencing different processes, such as cell migration by upregulating the expression of intercellular adhesion molecule-1 (ICAM-1) via PGE2 [46], and lymphoangiogenesis by regulating VEGF production [45, 118, 119]. VEGF is commonly overexpressed in OSCC, and COX-2/VEGF-C co-expression is correlated with lymphoangiogenesis, lymph node metastasis, and TNM stage and is reported as an independent factor for survival [45]. Increased VEGF expression in oral cancer is also a consequence of tumor-associated hypoxia, as VEGF is upregulated in decreasing concentrations of oxygen $[120,121]$. In reduced oxygen concentrations, hypoxia-inducible factor- $1 \alpha$ (HIF-1 $\alpha$ ) binds to hypoxia response elements and upregulates VEGF, promoting angiogenesis [122]. In OSCC, HIF- $1 \alpha$ and HIF- $2 \alpha$ correlate positively with clinical-pathological parameters, such as tumor size and micro vessel density, and in vivo experiments have shown their knockdown to reduce tumor angiogenesis and tumor growth [123]. In addition, hypoxia will also promote an inflammatory state, as VEGF is able to induce COX-2 expression, which will result in the production of PGE2 and the activation of NF-кB [124].

\section{TGF- $\beta$}

TGF- $\beta$ is a multifunctional pro-inflammatory cytokine that can either inhibit or promote tumor formation and progression of many cancers, whether by inducing apoptosis and growth arrest and by inhibiting proliferation or by stimulating angiogenesis, inflammation, EMT, and immune suppression, respectively [125]. If TGF- $\beta$ acts as a tumor suppressor or tumor promoter depends on the regional and cellular context [126]. In OSCC, TGF- $\beta$ is reported to promote tumorigenesis [17]. This is supported by the fact that OPMDs [18] and OSCC [19, 127] express higher levels of TGF- $\beta$ than healthy controls and that high TGF- $\beta$ levels are associated with disease recurrence and poor prognosis in patients with OSCC [19]. There are different mechanisms by which TGF- $\beta$ could act as a tumor promoter in oral cancer. TGF- $\beta$ is probably the most important factor involved in the differentiation of CAFs, and the accumulation of CAFs is reported as an independent prognostic factor in OSCC. CAFs are able to modulate the TME, facilitating cancer progression [128]. An in vivo mouse model in which TGF- $\beta 1$ was transgenically induced revealed that TGF- $\beta 1$ induced epithelia hyperproliferation, severe inflammation, and angiogenesis at similar levels to those observed in HNSCCs, suggesting that TGF- $\beta 1$ provides a tumor-promoting microenvironment [17]. In OPMDs, TGF- $\beta$ promotes a more malignant phenotype by increasing cell motility via the protein phosphatase 1 (PP-1) signaling pathway [129]. TGF- $\beta$ seems to be important for EMT development, as TGF- $\beta$ induces EMT in endothelial cells, and endothelial cells cultured with TGF- $\beta$ are able to induce EMT in OSCC cells [130]. Also, TGF- $\beta$ is able to induce EMT by stimulating the expression of ADAM12 (a desintegrin and metalloprotease associated with cancers) [131].

\section{Immunosuppressive Cytokines}

Anti-inflammatory cytokines also have a role in the oral carcinogenesis process. They can act as a double-edged sword, they can counteract the tumorigenic potential of their pro-inflammatory counterpart, and they can act as immunosuppressive molecules by decreasing the anti-tumor immune response [132]. Different immunosuppressive cytokines have been reported to have different roles in OSCC development (Table 1), with IL-1RA, IL-4, IL-10, and IL-13 being the most commonly investigated. IL-1RA decreases during the oral carcinogenesis process [20] and ILIRN (the gene that codes for IL-1RA) is downregulated in HNSCC [133, 134]. This in theory would allow higher IL-1 activity with the aforementioned effects. Nevertheless, high IL1-RA expression has been reported in advanced and poorly differentiated OSCCs [20,24], suggesting that IL-1RA expression could increase tumor progression, but this needs further investigation. IL-4, IL-10, and IL-13 have also been reported to increase in OSCC patients compared to healthy controls $[24,25,135]$, and high IL-10 expression has been associated with a more aggressive OSCC phenotype [136]. IL-4 induces immune deviation from $\mathrm{T}_{\mathrm{H}} 1$ to $\mathrm{T}_{\mathrm{H}} 2$ responses, which prevents tumor rejection [137]; IL-10 suppresses the anti-tumor immunity and contributes to tumor immune escape [135] and IL-13 compromises the anti-tumor response by inhibiting IFN- $\gamma$ secretion and CD8+ T lymphocyte activity [138].

\section{SOURCES OF INFLAMMATION}

Within the TME, cancer cells are not the only source of inflammatory molecules. Tumors are complex systems composed not only of neoplastic cells but also of stromal cells, which form the TME. These cells are not innocent bystanders and can interact with tumor cells and modify the extracellular matrix, facilitating and promoting proliferation, invasion, angiogenesis, and metastasis [49, 139]. Single cell profile of 5,578 samples obtained from 18 OSCCs revealed the presence of nine clusters of cells based on known marker genes, such as epithelial cells (malignant and non-malignant, based on CNV and their karyotypes), $\mathrm{T}$ cells (four sub-clusters), B/plasma cells, macrophages, dendritic cells, mast cells, endothelial cells, fibroblasts (three sub-clusters), and myocytes [140], which shows how heterogeneous tumors are.

As discussed previously, malignant oral keratinocytes (which are genetically unstable) activate different transcription factors, such as AP-1 and NF- $\kappa$ B, leading to the activation of oncogenes (which induces proliferation by the regulation of apoptosis, angiogenesis, and cell growth), and inflammatory genes [6]. The latter results in the constitutive production of different inflammatory factors, such as IL-1, IL-6, IL-8, TNF- $\alpha$, and 
TGF- $\beta$ [141], among many others, that can activate the same transcription factors, creating a positive feedback loop.

TAMs, T lymphocytes, neutrophils, and mast cells are also considered important sources of inflammatory mediators [5]. TAMs promote proliferation and invasion in OSCC [142, 143], and their presence correlates with disease progression and is considered an adverse prognostic factor [144]. They act as an important source of cytokines, metalloproteinases, and growth factors [95]. T lymphocytes are considered the most abundant inflammatory cells among the inflammatory infiltrate observed in OSCCs and can be beneficial or detrimental for oral carcinogenesis depending on their secretion profile [145]. They can secrete molecules that favor tumor progression (IL-6, IL-17, IL-23, TNF- $\alpha$, and TGF- $\beta$ ) or molecules that exhibit an anti-tumor effect (IL-12 and IFN- $\gamma$ ) [49]. Neutrophil infiltration increases OSCC invasion by inducing matrix degradation and invadopodia formation through a paracrine TNF- $\alpha$-induced mechanism [5, 16]. Mast cells have been associated with angiogenesis and are able to secrete numerous cytokines, chemokines, and angiogenic factors [146, 147], but their role in the development of OSCC is still debatable.

Cancer-associated fibroblasts, the most dominant components of the TME, are recipients of many of these factors (e.g., TGF- $\beta$ ), as well as directly contributing to tumor progression and an inflammatory TME via the secretion of VEGF, IL-6, IL-8, PGE2, TGF- $\beta$, and activation of NF-кB [148]. The presence and activity of CAFs are associated with poorer prognostic outcomes for OSCC [149] and are involved in bone invasion [150].

Senescent cells (which are more prevalent in older individuals, same as cancer) also contribute to chronic inflammation. When cells senesce, they develop an inflammatory secretory phenotype known as the senescent-associated secretory phenotype (SASP) [151], characterized by the secretion of high levels of "prooncogenic cytokines," such as IL-1, IL-6, and IL-8 [152]. In fact, the SASP is currently recognized as a cancer promoter mechanism, as it can induce EMT, invasion, and metastasis $[151,153]$, and its regulation has been proposed as anti-cancer treatment $[154,155]$.

\section{DIAGNOSTIC POTENTIAL}

Due to the advantages of using saliva samples (non-invasive and cost-efficient) for diagnostic and disease screening purposes, different studies have explored the possibility of using salivary inflammatory factors as biomarkers for the development and progression of OSCC. The most studied inflammatory proteins are TNF- $\alpha[5,14,42,141,156-159]$, IL-1 [5, 14, 141, 160, 161], IL-6 [5, 14, 34, 42, 92, 141, 158, 159, 162-164], and IL-8 [2, 5, $14,42,141,160,161,164]$ (NF-kB-dependent cytokines), which have been found to be increased in the saliva of patients with different OPMDs (including OLP, oral leukoplakia, verrucous proliferative leucoplakia, and oral submucous fibrosis) and OSCC in comparison to healthy controls. Other cytokines, such as MIP-1 $\beta$ and IFN $\gamma$ [14], and the anti-inflammatory cytokines IL-10 and IL-13 [24] have also been found to be increased in the saliva of patients with OSCC.
Using an array that analyzed the expression of 50 cytokines present in the saliva of patients with stage I OSCC before and after surgical treatment, Kamatani et al. [101] showed a significant decrease in salivary IL- $1 \beta$ after surgical resection. Similar to this, higher salivary levels of IL-8, IL-6, IL-1 $\beta$, MIP$1 \beta$, and IP-10 before surgical intervention in patients with stage I OSCC were recently reported [165]. These results suggest that salivary inflammatory cytokines might be useful to monitor disease relapse.

A proteomic analysis of 60 saliva samples from healthy individuals and patients with OPMD and OSCC detected 21 proteins differentially expressed in OSCC compared to those in the other groups. Among those, three proteins were selected for further validation using ELISA, which included the interleukin-1 receptor antagonist (IL-1RA). Salivary IL1RA was significantly decreased in patients with OPMD and control individuals compared to that in patients with OSCC but, alone, was suboptimal for distinguishing patients with OPMDs and healthy controls from patients with OSCC. In combination with other biomarkers (SLC3A2 and S100A2), IL-1RA was able to distinguish patients with OSCC from both healthy individuals and patients with OPMD with a sensitivity and specificity of $83.33 / 83.33 \%$ and of $93.33 / 70 \%$, respectively [21]. Salivary IL-1 $\beta$ and IL- 8 have also been found to discriminate between healthy individuals and patients with OSCC $[160,166]$ and high sensitivity and specificity values have been reported $(86 / 97 \%$ for IL- 8 and $83 / 76 \%$ for IL- $1 \beta$ ) $[166,167]$. Nevertheless, a recent systematic review reported average sensitivity and specificity values of $41 / 69 \%$ for IL-8 and of $26 / 46 \%$ for IL- $1 \beta$ [94], which are suboptimal. Both cytokines performed better when used in combination with other markers [161, 166], so it is likely that their future use will be as part of a panel of salivary biomarkers, rather than as single markers.

IL-6 is also a promising biomarker for the development of OSCC. IL-6 salivary levels are reported to increase with the severity of oral dysplasia [34], to differentiate between OPMD and OSCC (sensitivity and specificity values of 96 and 99\%, respectively) [163], and to predict treatment outcomes in patients with OSCC [11, 97]. High salivary expression of TNF- $\alpha$, IL- $1 \alpha$, and IL-8 has also been associated with a decreased survival rate in tongue squamous cell carcinoma (TSCC) [11].

\section{FUTURE DIRECTION}

The understanding of the role and origin of the different inflammatory molecules involved during tumor initiation, promotion, and progression of oral cancers provides an opportunity to target inflammation to improve patient outcomes. This can be done by selectively targeting transcription pathways (e.g., NF- $\mathrm{BB}$ ), cytokines (e.g., IL$1)$, or cell types known to contribute to the inflammatory secretome (e.g., CAFs and senescent cells). There are several research lines in this field, but little has been translated into the clinics, especially with regard to OSCC. Although all of the aforementioned reports are pointing in the direction that salivary cytokines could be used for diagnostic 
and prognostic aims in patients with oral cancer, more prospective studies are needed before they could be used in clinical settings.

\section{REFERENCES}

1. Voronov E, Dinarello CA, Apte RN. Interleukin-1alpha as an intracellular alarmin in cancer biology. Semin Immunol. (2018) 38:3-14. doi: 10.1016/j.smim.2018.10.006

2. Portier M, Zhang XG, Ursule E, Lees D, Jourdan M, Bataille R, et al. Cytokine gene expression in human multiple myeloma. $\mathrm{Br} J$ Haematol. (1993) 85:514-20. doi: 10.1111/j.1365-2141.1993.tb03341.x

3. Kuper H, Adami HO, Trichopoulos D. Infections as a major preventable cause of human cancer. J Intern Med. (2000) 248:171-83. doi: 10.1046/j.1365-2796.2000.00742.x

4. Apte RN, Dotan S, Elkabets M, White MR, Reich E, Carmi Y, et al. The involvement of IL-1 in tumorigenesis, tumor invasiveness, metastasis, and tumor-host interactions. Cancer Metastasis Rev. (2006) 25:387408. doi: 10.1007/s10555-006-9004-4

5. Goertzen C, Mahdi H, Laliberte C, Meirson T, Eymael D, Gil-Henn H, et al. Oral inflammation promotes oral squamous cell carcinoma invasion. Oncotarget. (2018) 9:29047-63. doi: 10.18632/oncotarget.25540

6. Rao SK, Pavicevic Z, Du Z, Kim JG, Fan M, Jiao Y, et al. Pro-inflammatory genes as biomarkers and therapeutic targets in oral squamous cell carcinoma. J Biol Chem. (2010) 285:32512-21. doi: 10.1074/jbc.M110.150490

7. Wu T, Hong Y, Jia L, Wu J, Xia J, Wang J, et al. Modulation of IL-1beta reprogrammes the tumor microenvironment to interrupt oral carcinogenesis. Sci Rep. (2016) 6:20208. doi: 10.1038/srep20208

8. Speight PM, Khurram SA, Kujan O. Oral potentially malignant disorders: risk of progression to malignancy. Oral Surg Oral Med Oral Pathol Oral Radiol. (2018) 125:612-27. doi: 10.1016/j.oooo.2017.12.011

9. Lee CH, Chang JS, Syu SH, Wong TS, Chan JY, Tang YC, et al. IL-1beta promotes malignant transformation and tumor aggressiveness in oral cancer. J Cell Physiol. (2015) 230:875-84. doi: 10.1002/jcp.24816

10. Leon X, Bothe C, Garcia J, Parreno M, Alcolea S, Quer M, et al. Expression of IL-1alpha correlates with distant metastasis in patients with head and neck squamous cell carcinoma. Oncotarget. (2015) 6:37398409. doi: 10.18632/oncotarget.6054

11. Korostoff A, Reder L, Masood R, Sinha UK. The role of salivary cytokine biomarkers in tongue cancer invasion and mortality. Oral Oncol. (2011) 47:282-7. doi: 10.1016/j.oraloncology.2011.02.006

12. Bates AM, Gomez Hernandez MP, Lanzel EA, Qian F, Brogden KA. Matrix metalloproteinase (MMP) and immunosuppressive biomarker profiles of seven head and neck squamous cell carcinoma (HNSCC) cell lines. Transl Cancer Res. (2018) 7:533-42. doi: 10.21037/tcr.2018.05.09

13. Sun Y, Zhu D, Wang G, Wang D, Zhou H, Liu X, et al. Pro-inflammatory cytokine IL-1 $\beta$ up-regulates CXC chemokine receptor 4 via notch and ERK signaling pathways in tongue squamous cell carcinoma. PLoS ONE. (2015) 10:e0132677. doi: 10.1371/journal.pone.0132677

14. Lee LT, Wong YK, Hsiao HY, Wang YW, Chan MY, Chang KW. Evaluation of saliva and plasma cytokine biomarkers in patients with oral squamous cell carcinoma. Int J Oral Maxillofac Surg. (2018) 47:699707. doi: 10.1016/j.ijom.2017.09.016

15. Cohen RF, Contrino J, Spiro JD, Mann EA, Chen LL, Kreutzer DL. Interleukin-8 expression by head and neck squamous cell carcinoma. Arch Otolaryngol Head Neck Surg. (1995) 121:202-9. doi: 10.1001/archotol.1995.01890020064013

16. Glogauer JE, Sun CX, Bradley G, Magalhaes MA. Neutrophils increase oral squamous cell carcinoma invasion through an invadopodia-dependent pathway. Cancer Immunol Res. (2015) 3:1218-26. doi: 10.1158/2326-6066.CIR-15-0017

17. Lu SL, Reh D, Li AG, Woods J, Corless CL, Kulesz-Martin M, et al. Overexpression of transforming growth factor betal in head and neck epithelia results in inflammation, angiogenesis,

\section{AUTHOR CONTRIBUTIONS}

SN performed the review and wrote the manuscript.

and epithelial hyperproliferation. Cancer Res. (2004) 64:440510. doi: 10.1158/0008-5472.CAN-04-1032

18. Gonçalves AS, Mosconi C, Jaeger F, Wastowski IJ, Aguiar MCF, Silva TA, et al. Overexpression of immunomodulatory mediators in oral precancerous lesions. Hum Immunol. (2017) 78:752-7. doi: 10.1016/j.humimm.2017.09.003

19. Lu Z, Ding L, Ding H, Hao F, Pu Y, Wang Y, et al. Tumor cell-derived TGF- $\beta$ at tumor center independently predicts recurrence and poor survival in oral squamous cell carcinoma. J Oral Pathol Med. (2019) 48:696704. doi: 10.1111/jop.12888

20. Shiiba M, Saito K, Yamagami H, Nakashima D, Higo M, Kasamatsu A, et al. Interleukin-1 receptor antagonist (IL1RN) is associated with suppression of early carcinogenic events in human oral malignancies. Int J Oncol. (2015) 46:1978-84. doi: 10.3892/ijo.2015.2917

21. Shan J, Sun Z, Yang J, Xu J, Shi W, Wu Y, et al. Discovery and preclinical validation of proteomic biomarkers in saliva for early detection of oral squamous cell carcinomas. Oral Dis. (2019) 25:97107. doi: 10.1111/odi.12971

22. Manchanda P, Sharma SC, Das SN. Differential regulation of IL-2 and IL-4 in patients with tobacco-related oral squamous cell carcinoma. Oral Dis. (2006) 12:455-62. doi: 10.1111/j.1601-0825.2005.01220.x

23. Beppu M, Ikebe T, Shirasuna K. The inhibitory effects of immunosuppressive factors, dexamethasone and interleukin-4, on NF-kappaB-mediated protease production by oral cancer. Biochim Biophys Acta. (2002) 1586:1122. doi: 10.1016/S0925-4439(01)00080-1

24. Aziz S, Ahmed SS, Ali A, Khan FA, Zulfiqar G, Iqbal J, et al. Salivary immunosuppressive cytokines IL-10 and IL-13 are significantly elevated in oral squamous cell carcinoma patients. Cancer Invest. (2015) 33:31828. doi: 10.3109/07357907.2015.1041642

25. Alhamarneh O, Agada F, Madden L, Stafford N, Greenman J. Serum IL10 and circulating CD4(+) CD25(high) regulatory $\mathrm{T}$ cell numbers as predictors of clinical outcome and survival in patients with head and neck squamous cell carcinoma. Head Neck. (2011) 33:415-23. doi: 10.1002/hed. 21464

26. Arantes DA, Costa NL, Mendonça EF, Silva TA, Batista AC. Overexpression of immunosuppressive cytokines is associated with poorer clinical stage of oral squamous cell carcinoma. Arch Oral Biol. (2016) 61:2835. doi: 10.1016/j.archoralbio.2015.10.013

27. Adappa ND, Sung CK, Choi B, Huang TG, Genden EM, Shin EJ. The administration of IL-12/GM-CSF and Ig-4-1BB ligand markedly decreases murine floor of mouth squamous cell cancer. Otolaryngol Head Neck Surg. (2008) 139:442-8. doi: 10.1016/j.otohns.2008.05.001

28. Tian S, Jiang C, Liu X, Xu S, Zhang Z, Chen H, et al. Hypermethylation of IFN- $\gamma$ in oral cancer tissues. Clin Oral Investig. (2017) 21:253542. doi: 10.1007/s00784-017-2052-z

29. Peng X, Li W, Johnson WD, Torres KE, McCormick DL. Overexpression of lipocalins and pro-inflammatory chemokines and altered methylation of PTGS2 and APC2 in oral squamous cell carcinomas induced in rats by 4-nitroquinoline-1-oxide. PLoS ONE. (2015) 10:e0116285. doi: 10.1371/journal.pone.0116285

30. Lee CH, Syu SH, Liu KJ, Chu PY, Yang WC, Lin P, et al. Interleukin-1 beta transactivates epidermal growth factor receptor via the CXCL1-CXCR2 axis in oral cancer. Oncotarget. (2015) 6:38866-80. doi: 10.18632/oncotarget.5640

31. Prasad G, McCullough M. Chemokines and cytokines as salivary biomarkers for the early diagnosis of oral cancer. Int J Dent. (2013) 2013:813756. doi: 10.1155/2013/813756

32. Lien MY, Lin CW, Tsai HC, Chen YT, Tsai MH, Hua CH, et al. Impact of CCL4 gene polymorphisms and environmental factors on oral cancer development and clinical characteristics. Oncotarget. (2017) 8:3142434. doi: 10.18632/oncotarget.15615 
33. Bae JY, Kim EK, Yang DH, Zhang X, Park YJ, Lee DY, et al. Reciprocal interaction between carcinoma-associated fibroblasts and squamous carcinoma cells through interleukin-1alpha induces cancer progression. Neoplasia. (2014) 16:928-38. doi: 10.1016/j.neo.2014.09.003

34. Sharma M, Bairy I, Pai K, Satyamoorthy K, Prasad S, Berkovitz B, et al. Salivary IL-6 levels in oral leukoplakia with dysplasia and its clinical relevance to tobacco habits and periodontitis. Clin Oral Investig. (2011) 15:705-14. doi: 10.1007/s00784-010-0435-5

35. Abdullah Zubir AZ, Whawell SA, Wong TS, Khurram SA. The chemokine lymphotactin and its recombinant variants in oral cancer cell regulation. Oral Dis. (2020) 26:1668-76. doi: 10.1111/odi.13500

36. Khurram SA, Bingle L, McCabe BM, Farthing PM, Whawell SA. The chemokine receptors CXCR1 and CXCR2 regulate oral cancer cell behaviour. J Oral Pathol Med. (2014) 43:667-74. doi: 10.1111/jop.12191

37. Timmons SR, Nwankwo JO, Domann FE. Acetaldehyde activates Jun/AP1 expression and DNA binding activity in human oral keratinocytes. Oral Oncol. (2002) 38:281-90. doi: 10.1016/S1368-8375(01)00056-2

38. Alam M, Kashyap T, Pramanik KK, Singh AK, Nagini S, Mishra R. The elevated activation of NFKB and AP-1 is correlated with differential regulation of $\mathrm{Bcl}-2$ and associated with oral squamous cell carcinoma progression and resistance. Clin Oral Investig. (2017) 21:272131. doi: 10.1007/s00784-017-2074-6

39. Wolf JS, Chen Z, Dong G, Sunwoo JB, Bancroft CC, Capo DE, et al. IL (Interleukin)-1 promotes nuclear factor- B and AP-1-induced IL-8 expression, cell survival, and proliferation in head and neck squamous cell carcinomas. Clin Cancer Res. (2001) 7:1812-20.

40. Nakayama H, Ikebe T, Beppu M, Shirasuna K. High expression levels of nuclear factor kappaB, IkappaB kinase alpha and Akt kinase in squamous cell carcinoma of the oral cavity. Cancer. (2001) 92:3037-44. doi: 10.1002/ 1097-0142(20011215)92:12<3037::AID-CNCR10171>3.0.CO;2-\#

41. Tanaka T, Nakayama H, Yoshitake $Y$, Irie A, Nagata M, Kawahara K, et al. Selective inhibition of nuclear factor- $\kappa \mathrm{B}$ by nuclear factor- $\kappa \mathrm{B}$ essential modulator-binding domain peptide suppresses the metastasis of highly metastatic oral squamous cell carcinoma. Cancer Sci. (2012) 103:45563. doi: 10.1111/j.1349-7006.2011.02174.x

42. Zhang Y, Lin M, Zhang S, Wang Z, Jiang L, Shen J, et al. NF-kappaBdependent cytokines in saliva and serum from patients with oral lichen planus: a study in an ethnic Chinese population. Cytokine. (2008) 41:1449. doi: 10.1016/j.cyto.2007.11.004

43. Liu YC, Ho HC, Lee MR, Lai KC, Yeh CM, Lin YM, et al. Early induction of cytokines/cytokine receptors and Cox2, and activation of NF- $\mathrm{B}$ in 4 nitroquinoline 1-oxide-induced murine oral cancer model. Toxicol Appl Pharmacol. (2012) 262:107-16. doi: 10.1016/j.taap.2012.04.023

44. Shibata M, Kodani I, Osaki M, Araki K, Adachi H, Ryoke K, et al. Cyclooxygenase-1 and-2 expression in human oral mucosa, dysplasias and squamous cell carcinomas and their pathological significance. Oral Oncol. (2005) 41:304-12. doi: 10.1016/j.oraloncology.2004.09.009

45. Morita Y, Morita N, Hata K, Nakanishi M, Kimoto N, Omata T, et al. Cyclooxygenase-2 expression is associated with vascular endothelial growth factor-c and lymph node metastasis in human oral tongue cancer. Oral Surg Oral Med Oral Pathol Oral Radiol. (2014) 117:50210. doi: 10.1016/j.oooo.2013.12.410

46. Yang SF, Chen MK, Hsieh YS, Chung TT, Hsieh YH, Lin CW, et al. Prostaglandin E2/EP1 signaling pathway enhances intercellular adhesion molecule 1 (ICAM-1) expression and cell motility in oral cancer cells. J Biol Chem. (2010) 285:29808-16. doi: 10.1074/jbc.M110.108183

47. Postler TS, Ghosh S. Bridging the gap: a regulator of NF$\kappa \mathrm{B}$ linking inflammation and cancer. J Oral Biosci. (2015) 57:143-7. doi: 10.1016/j.job.2015.05.001

48. Jimi E, Kokabu S, Matsubara T, Nakatomi C, Matsuo K, Watanabe S. NF-кB acts as a multifunctional modulator in bone invasion by oral squamous cell carcinoma. Oral Sci Int. (2016) 13:1-6. doi: 10.1016/S1348-8643(15)00038-5

49. Tampa M, Mitran MI, Mitran CI, Sarbu MI, Matei C, Nicolae $\mathrm{I}$, et al. Mediators of inflammation - a potential source of biomarkers in oral squamous cell carcinoma. I Immunol Res. (2018) 2018:1061780. doi: 10.1155/2018/1061780

50. Garat C, Arend WP. Intracellular IL-1Ra type 1 inhibits IL-1-induced IL-6 and IL- 8 production in Caco-2 intestinal epithelial cells through inhibition of p38 mitogen-activated protein kinase and NF-kappaB pathways. Cytokine. (2003) 23:31-40. doi: 10.1016/S1043-4666(03)00182-0

51. Papa S, Bubici C, Zazzeroni F, Pham CG, Kuntzen C, Knabb JR, et al. The NF-kappaB-mediated control of the JNK cascade in the antagonism of programmed cell death in health and disease. Cell Death Differ. (2006) 13:712-29. doi: 10.1038/sj.cdd.4401865

52. Julien S, Puig I, Caretti E, Bonaventure J, Nelles L, van Roy F, et al. Activation of NF-kappaB by Akt upregulates snail expression and induces epithelium mesenchyme transition. Oncogene(2007) 26:744556. doi: 10.1038/sj.onc. 1210546

53. Wu D, Wu P, Zhao L, Huang L, Zhang Z, Zhao S, et al. NF-кB expression and outcomes in solid tumors: a systematic review and meta-analysis. Medicine. (2015) 94:e1687. doi: 10.1097/MD.0000000000001687

54. Yang X, Cheng H, Chen J, Wang R, Saleh A, Si H, et al. Head and neck cancers promote an inflammatory transcriptome through coactivation of classic and alternative NF-kB pathways. Cancer Immunol Res. (2019) 7:176074. doi: 10.1158/2326-6066.CIR-18-0832

55. Zhang J, Peng B. NF-kappaB promotes iNOS and VEGF expression in salivary gland adenoid cystic carcinoma cells and enhances endothelial cell motility in vitro. Cell Prolif. (2009) 42:150-61. doi: 10.1111/j.1365-2184.2009.00588.x

56. Ikebe T, Takeuchi H, Jimi E, Beppu M, Shinohara M, Shirasuna K. Involvement of proteasomes in migration and matrix metalloproteinase- 9 production of oral squamous cell carcinoma. Int J Cancer. (1998) 77:57885. doi: 10.1002/(SICI)1097-0215(19980812)77:4<578::AID-IJC18>3.0. CO;2-2

57. Lin Z, Sun L, Chen W, Liu B, Wang Y, Fan S, et al. miR-639 regulates transforming growth factor beta-induced epithelial-mesenchymal transition in human tongue cancer cells by targeting FOXC1. Cancer Sci. (2014) 105:1288-98. doi: 10.1111/cas.12499

58. Wang Y, Lin Z, Sun L, Fan S, Huang Z, Zhang D, et al. Akt/Ezrin Tyr353/NF$\kappa \mathrm{B}$ pathway regulates EGF-induced EMT and metastasis in tongue squamous cell carcinoma. Br J Cancer. (2014) 110:695-705. doi: 10.1038/bjc.2013.770

59. Ma T, Zhao Z, Wang Z, Wang C, Zhang L. MiR-940 inhibits migration and invasion of tongue squamous cell carcinoma via regulatingCXCR2/NF-kB system-mediated epithelial-mesenchymal transition. Naunyn Schmiedebergs Arch Pharmacol. (2019) 392:1359-69. doi: 10.1007/s00210-019-01671-w

60. Duffey DC, Chen Z, Dong G, Ondrey FG, Wolf JS, Brown K, et al. Expression of a dominant-negative mutant inhibitor-kappaBalpha of nuclear factorkappaB in human head and neck squamous cell carcinoma inhibits survival, proinflammatory cytokine expression, and tumor growth in vivo. Cancer Res. (1999) 59:3468-74.

61. Shaulian E, Karin M. AP-1 as a regulator of cell life and death. Nat Cell Biol. (2002) 4:E131-6. doi: 10.1038/ncb0502-e131

62. Fujioka S, Niu J, Schmidt C, Sclabas GM, Peng B, Uwagawa T, et al. NF-kappaB and AP-1 connection: mechanism of NF-kappaBdependent regulation of AP-1 activity. Mol Cell Biol. (2004) 24:780619. doi: 10.1128/MCB.24.17.7806-7819.2004

63. Riabowol K, Schiff J, Gilman MZ. Transcription factor AP-1 activity is required for initiation of DNA synthesis and is lost during cellular aging. Proc Natl Acad Sci U S A. (1992) 89:157-61. doi: 10.1073/pnas.89.1.157

64. Bunjobpol W, Dulloo I, Igarashi K, Concin N, Matsuo K, Sabapathy K. Suppression of acetylpolyamine oxidase by selected AP-1 members regulates DNp73 abundance: mechanistic insights for overcoming DNp73-mediated resistance to chemotherapeutic drugs. Cell Death Differ. (2014) 21:12409. doi: 10.1038/cdd.2014.41

65. Werman A, Werman-Venkert R, White R, Lee JK, Werman B, Krelin Y, et al. The precursor form of IL-1alpha is an intracrine proinflammatory activator of transcription. Proc Natl Acad Sci USA. (2004) 101:24349. doi: 10.1073/pnas.0308705101

66. Scott KA, Moore RJ, Arnott CH, East N, Thompson RG, Scallon BJ, et al. An anti-tumor necrosis factor-alpha antibody inhibits the development of experimental skin tumors. Mol Cancer Ther. (2003) 2:445-51.

67. Zhang L, Jiao M, Wu K, Li L, Zhu G, Wang X, et al. TNF- $\alpha$ induced epithelial mesenchymal transition increases stemness properties in renal cell carcinoma cells. Int J Clin Exp Med. (2014) 7:4951-8.

68. Johnston DA, Dong B, Hughes CC. TNF induction of jagged-1 in endothelial cells is NFkappaB-dependent. 
Gene. (2009) 435:36-44. doi: 10.1016/j.gene.2009.

01.003

69. Balkwill F. Tumour necrosis factor and cancer. Nat Rev Cancer. (2009) 9:361-71. doi: $10.1038 / \mathrm{nrc} 2628$

70. Mozaffari HR, Ramezani M, Mahmoudiahmadabadi M, Omidpanah N, Sadeghi M. Salivary and serum levels of tumor necrosis factoralpha in oral lichen planus: a systematic review and meta-analysis study. Oral Surg Oral Med Oral Pathol Oral Radiol. (2017) 124:e1839. doi: 10.1016/j.oooo.2017.06.117

71. Scheff NN, Ye Y, Bhattacharya A, MacRae J, Hickman DN, Sharma AK, et al. Tumor necrosis factor alpha secreted from oral squamous cell carcinoma contributes to cancer pain and associated inflammation. Pain. (2017) 158:2396-409. doi: 10.1097/j.pain.0000000000001044

72. Tang D, Tao D, Fang Y, Deng C, Xu Q, Zhou J. TNF-alpha promotes invasion and metastasis via NF-Kappa B pathway in oral squamous cell carcinoma. Med Sci Monit Basic Res. (2017) 23:141-9. doi: 10.12659/MSMBR.903910

73. Ren ZH, Wu K, Yang R, Liu ZQ, Cao W. Differential expression of matrix metalloproteinases and miRNAs in the metastasis of oral squamous cell carcinoma. BMC Oral Health. (2020) 20:24. doi: 10.1186/s12903-020-1013-0

74. de Vicente JC, Fresno MF, Villalain L, Vega JA, Hernández Vallejo G. Expression and clinical significance of matrix metalloproteinase-2 and matrix metalloproteinase-9 in oral squamous cell carcinoma. Oral Oncol. (2005) 41:283-93. doi: 10.1016/j.oraloncology.2004.08.013

75. Jimenez L, Jayakar SK, Ow TJ, Segall JE. Mechanisms of invasion in head and neck cancer. Arch Pathol Lab Med. (2015) 139:133448. doi: 10.5858/arpa.2014-0498-RA

76. Ricci S, Pinto F, Auletta A, Giordano A, Giovane A, Settembre G, et al. The enigmatic role of matrix metalloproteinases in epithelial-to-mesenchymal transition of oral squamous cell carcinoma: implications and nutraceutical aspects. J Cell Biochem. (2019) 120:6813-9. doi: 10.1002/jcb.26905

77. Horejs CM. Basement membrane fragments in the context of the epithelial-to-mesenchymal transition. Eur J Cell Biol. (2016) 95:42740. doi: $10.1016 /$ j.ejcb.2016.06.002

78. Chen IC, Chiang WF, Huang HH, Chen PF, Shen YY, Chiang HC. Role of SIRT1 in regulation of epithelial-to-mesenchymal transition in oral squamous cell carcinoma metastasis. Mol Cancer. (2014) 13:254. doi: 10.1186/1476-4598-13-254

79. Zhang S, Wang B, Zhou X, Yue K, Wang X. The experimental study of CXC subfamily receptor 4 modulating oral squamous cell carcinoma epithelialmesenchymal transition to influence lymphatic metastasis in vitro. Zhonghua Kou Qiang Yi Xue Za Zhi. (2014) 49:171-6.

80. Epanchintsev A, Shyamsunder P, Verma RS, Lyakhovich A. IL-6, IL8, MMP-2, MMP-9 are overexpressed in Fanconi anemia cells through a NF-kB/TNF- $\alpha$ dependent mechanism. Mol Carcinog. (2015) 54:168699. doi: $10.1002 / \mathrm{mc} .22240$

81. Tanaka $\mathrm{T}$, Imamura $\mathrm{T}$, Yoneda $\mathrm{M}$, Irie $\mathrm{A}, \mathrm{Ogi} \mathrm{H}$, Nagata $\mathrm{M}$, et al. Enhancement of active MMP release and invasive activity of lymph node metastatic tongue cancer cells by elevated signaling via the TNF- $\alpha$-TNFR1NF- $\mathrm{KB}$ pathway and a possible involvement of angiopoietin-like 4 in lung metastasis. Int J Oncol. (2016) 49:1377-84. doi: 10.3892/ijo.2016.3653

82. Bates RC, Mercurio AM. Tumor necrosis factor-alpha stimulates the epithelial-to-mesenchymal transition of human colonic organoids. Mol Biol Cell. (2003) 14:1790-800. doi: 10.1091/mbc.e02-09-0583

83. Kashyap T, Pramanik KK, Nath N, Mishra P, Singh AK, Nagini S, et al. Crosstalk between Raf-MEK-ERK and PI3K-Akt-GSK3 $\beta$ signaling networks promotes chemoresistance, invasion/migration and stemness via expression of CD44 variants (v4 and v6) in oral cancer. Oral Oncol. (2018) 86:23443. doi: 10.1016/j.oraloncology.2018.09.028

84. Pai S, Bamodu OA, Lin YK, Lin CS, Chu PY, Chien MH, et al. CD47-SIRP $\alpha$ signaling induces epithelial-mesenchymal transition and cancer stemness and links to a poor prognosis in patients with oral squamous cell carcinoma. Cells. (2019) 8:1658. doi: 10.3390/cells 8121658

85. Liu M, Gao X, Liu CL. Increased expression of IncRNA FTH1P3 promotes oral squamous cell carcinoma cells migration and invasion by enhancing PI3K/Akt/GSK3b/ Wnt/B-catenin signaling. Eur Rev Med Pharmacol Sci. (2018) 22:8306-14. doi: 10.26355/eurrev_201812_16528

86. Wang H, Deng X, Zhang J, Ou Z, Mai J, Ding S, et al. Elevated expression of zinc finger protein 703 promotes cell proliferation and metastasis through
PI3K/AKT/GSK-3 $\beta$ signalling in oral squamous cell carcinoma. Cell Physiol Biochem. (2017) 44:920-34. doi: 10.1159/000485360

87. Lai KC, Liu CJ, Lin TJ, Mar AC, Wang HH, Chen CW, et al. Blocking TNF- $\alpha$ inhibits angiogenesis and growth of IFIT2-depleted metastatic oral squamous cell carcinoma cells. Cancer Lett. (2016) 370:20715. doi: 10.1016/j.canlet.2015.10.016

88. Coppe JP, Patil CK, Rodier F, Sun Y, Munoz DP, Goldstein J, et al. Senescenceassociated secretory phenotypes reveal cell-nonautonomous functions of oncogenic RAS and the p53 tumor suppressor. PLoS Biol. (2008) 6:285368. doi: 10.1371/journal.pbio.0060301

89. Sparmann A, Bar-Sagi D. Ras-induced interleukin-8 expression plays a critical role in tumor growth and angiogenesis. Cancer Cell. (2004) 6:44758. doi: 10.1016/j.ccr.2004.09.028

90. Ancrile B, Lim KH, Counter CM. Oncogenic ras-induced secretion of IL6 is required for tumorigenesis. Genes Dev. (2007) 21:17149. doi: 10.1101/gad.1549407

91. Loaiza N, Demaria M. Cellular senescence and tumor promotion: is aging the key? Biochim Biophys Acta. (2016) 1865:15567. doi: 10.1016/j.bbcan.2016.01.007

92. Panneer Selvam N, Sadaksharam J. Salivary interleukin-6 in the detection of oral cancer and precancer. Asia Pac J Clin Oncol. (2015) 11:23641. doi: 10.1111/ajco.12330

93. Dikova VR, Principe S, Bagan JV. Salivary inflammatory proteins in patients with oral potentially malignant disorders. J Clin Exp Dent. (2019) 11:e65964. doi: $10.4317 /$ jced. 55917

94. Gaba FI, Sheth CC, Veses V. Salivary biomarkers and their efficacies as diagnostic tools for oral squamous cell carcinoma: systematic review and meta-analysis. J Oral Pathol Med. (2018) 1-9. doi: 10.1111/jop.12791. [Epub ahead of print].

95. Zhou J, Tang Z, Gao S, Li C, Feng Y, Zhou X. Tumor-associated macrophages: recent insights and therapies. Front Oncol. (2020) 10:188. doi: $10.3389 /$ fonc. 2020.00188

96. Waugh DJ, Wilson C. The interleukin-8 pathway in cancer. Clin Cancer Res. (2008) 14:6735-41. doi: 10.1158/1078-0432.CCR-07-4843

97. Tsai MS, Chen WC, Lu CH, Chen MF. The prognosis of head and neck squamous cell carcinoma related to immunosuppressive tumor microenvironment regulated by IL-6 signaling. Oral Oncol. (2019) 91:4755. doi: 10.1016/j.oraloncology.2019.02.027

98. Woods RV, Adler-Storthz K, Dayman GL, Francis GM, Grimm EA. Interleukin-1 regulates interleukin-6 secretion in human oral squamous cell carcinoma in vitro: possible influence of $\mathrm{p} 53$ but not human papillomavirus E6/E. Cancer Res. (1998) 58:3142-9.

99. von Biberstein SE, Spiro JD, Lindquist R, Kreutzer DL. Interleukin-1 receptor antagonist in head and neck squamous cell carcinoma. Arch Otolaryngol Head Neck Surg. (1996) 122:751-9. doi: 10.1001/archotol.1996.018901900 47012

100. SahebJamee M, Eslami M, AtarbashiMoghadam F, Sarafnejad A. Salivary concentration of TNF $\alpha$, IL1 $\alpha$, IL6, and IL8 in oral squamous cell carcinoma. Med Oral Patol Oral Cir Bucal. (2008) 13:E292-5.

101. Kamatani T, Shiogama S, Yoshihama Y, Kondo S, Shirota T, Shintani S. Interleukin-1 beta in unstimulated whole saliva is a potential biomarker for oral squamous cell carcinoma. Cytokine. (2013) 64:497502. doi: 10.1016/j.cyto.2013.08.011

102. Stevenson FT, Turck J, Locksley RM, Lovett DH. The N-terminal propiece of interleukin 1 is a transforming nuclear oncoprotein. Cell Biol. (1997) 94:508-13. doi: 10.1073/pnas.94.2.508

103. Lee CH, Wong TS, Chan JY, Lu SC, Lin P, Cheng AJ, et al. Epigenetic regulation of the X-linked tumour suppressors BEX1 and LDOC1 in oral squamous cell carcinoma. J Pathol. (2013) 230:298309. doi: 10.1002/path.4173

104. Al-Sahaf S, Hunter KD, Bolt R, Ottewell PD, Murdoch C. The IL-1/IL-1R axis induces greater fibroblast-derived chemokine release in human papillomavirus-negative compared to positive oropharyngeal cancer. Int J Cancer. (2019) 144:334-44. doi: 10.1002/ijc. 31852

105. Banda NK, Guthridge C, Sheppard D, Cairns KS, Muggli M, BechOtschir D, et al. Intracellular IL-1 receptor antagonist type 1 inhibits IL1 -induced cytokine production in keratinocytes through binding to the 
third component of the COP9 signalosome. J Immunol. (2005) 174:360816. doi: 10.4049/jimmunol.174.6.3608

106. Hashemi Goradel N, Najafi M, Salehi E, Farhood B, Mortezaee K. Cyclooxygenase-2 in cancer: a review. J Cell Physiol. (2019) 234:568399. doi: $10.1002 /$ jcp. 27411

107. Schellhorn $M$, Haustein $M$, Frank $M$, Linnebacher $M$, Hinz B. Celecoxib increases lung cancer cell lysis by lymphokineactivated killer cells via upregulation of ICAM-1. Oncotarget. (2015) 6:39342-56. doi: 10.18632/oncotarget.5745

108. Chu TH, Chan HH, Kuo HM, Liu LF, Hu TH, Sun CK, et al. Celecoxib suppresses hepatoma stemness and progression by up-regulating PTEN. Oncotarget. (2014) 5:1475-90. doi: 10.18632/oncotarget.1745

109. Choi YH, Back KO, Kim HJ, Lee SY, Kook KH. Pirfenidone attenuates IL-1 $\beta$-induced COX-2 and PGE2 production in orbital fibroblasts through suppression of NF-kB activity. Exp Eye Res. (2013) 113:1-8. doi: 10.1016/j.exer.2013.05.001

110. Konstantinopoulos PA, Vandoros GP, Karamouzis MV, Gkermpesi M, Sotiropoulou-Bonikou G, Papavassiliou AG. EGF-R is expressed and AP-1 and NF-kappaB are activated in stromal myofibroblasts surrounding colon adenocarcinomas paralleling expression of COX-2 and VEGF. Cell Oncol. (2007) 29:477-82. doi: 10.1155/2007/831416

111. Fang L, Chang HM, Cheng JC, Leung PC, Sun YP. TGF- $\beta 1$ induces COX2 expression and PGE2 production in human granulosa cells through Smad signaling pathways. J Clin Endocrinol Metab. (2014) 99:E121726. doi: $10.1210 /$ jc. $2013-4100$

112. Nakao S, Ogtata Y, Shimizu E, Yamazaki M, Furuyama S, Sugiya H. Tumor necrosis factor alpha (TNF-alpha)-induced prostaglandin E2 release is mediated by the activation of cyclooxygenase-2 (COX-2) transcription via NFkappaB in human gingival fibroblasts. Mol Cell Biochem. (2002) 238:11-8. doi: 10.1023/A:1019927616000

113. Amirchaghmaghi M, Mohtasham N, Mozaffari PM. Comparison of COX2 expression between oral squamous cell carcinoma, leukoplakia and normal mucosa. J Contemp Dent Pract. (2012) 13:205-9. doi: 10.5005/jp-journals-10024-1122

114. Chan G, Boyle JO, Yang EK, Zhang F, Sacks PG, Shah JP, et al. Cyclooxygenase-2 expression is up-regulated in squamous cell carcinoma of the head and neck. Cancer Res. (1999) 59:991-4.

115. Yang B, Jia L, Guo Q, Ren H, Hu Y, Xie T. Clinicopathological and prognostic significance of cyclooxygenase-2 expression in head and neck cancer: a metaanalysis. Oncotarget. (2016) 7:47265-77. doi: 10.18632/oncotarget.10059

116. Sano Y, Kogashiwa Y, Araki R, Enoki Y, Ikeda T, Yoda T, et al. Correlation of inflammatory markers, survival, and COX2 expression in oral cancer and implications for prognosis. Otolaryngol Head Neck Surg. (2018) 158:66776. doi: $10.1177 / 0194599817745284$

117. Nasry WHS, Rodriguez-Lecompte JC, Martin CK. Role of COX-2/PGE2 mediated inflammation in oral squamous cell carcinoma. Cancers. (2018) 10:348. doi: 10.3390/cancers 10100348

118. Wang $\mathrm{YH}, \mathrm{Wu} \mathrm{MW}$, Yang AK, Zhang WD, Sun J, Liu TR, et al. COX-2 gene increases tongue cancer cell proliferation and invasion through VEGF-C pathway. Med Oncol. (2011) 28(Suppl. 1):S360-6. doi: 10.1007/s12032-010-9737-3

119. Kono M, Watanabe M, Abukawa $\mathrm{H}$, Hasegawa $\mathrm{O}$, Satomi $\mathrm{T}$, Chikazu D. Cyclo-oxygenase-2 expression is associated with vascular endothelial growth factor C expression and lymph node metastasis in oral squamous cell carcinoma. J Oral Maxillofac Surg. (2013) 71:1694-702. doi: 10.1016/j.joms.2013.04.015

120. Shang ZJ, Li ZB, Li JR. VEGF is up-regulated by hypoxic stimulation and related to tumour angiogenesis and severity of disease in oral squamous cell carcinoma: in vitro and in vivo studies. Int J Oral Maxillofac Surg. (2006) 35:533-8. doi: 10.1016/j.ijom.2005.09.006

121. Lee LT, Wong YK, Chan MY, Chang KW, Chen SC, Chang CT, et al. The correlation between HIF-1 alpha and VEGF in oral squamous cell carcinomas: expression patterns and quantitative immunohistochemical analysis. J Chin Med Assoc. (2018) 81:370-5. doi: 10.1016/j.jcma.2017.06.025

122. Pouysségur J, Dayan F, Mazure NM. Hypoxia signalling in cancer and approaches to enforce tumour regression. Nature. (2006) 441:43743. doi: $10.1038 /$ nature 04871
123. Zhu GQ, Tang YL, Li L, Zheng M, Jiang J, Li XY, et al. Hypoxia inducible factor $1 \alpha$ and hypoxia inducible factor $2 \alpha$ play distinct and functionally overlapping roles in oral squamous cell carcinoma. Clin Cancer Res. (2010) 16:4732-41. doi: 10.1158/1078-0432.CCR-10-1408

124. Aguilar-Cazares D, Chavez-Dominguez R, Carlos-Reyes A, LopezCamarillo C, Hernadez de la Cruz ON, Lopez-Gonzalez JS. Contribution of angiogenesis to inflammation and cancer. Front Oncol. (2019) 9:1399. doi: $10.3389 /$ fonc.2019.01399

125. Wu F, Weigel KJ, Zhou H, Wang XJ. Paradoxical roles of TGF- $\beta$ signaling in suppressing and promoting squamous cell carcinoma. Acta Biochim Biophys Sin. (2018) 50:98-105. doi: 10.1093/abbs/gmx127

126. Massagué J. TGF $\beta$ signalling in context. Nat Rev Mol Cell Biol. (2012) 13:616-30. doi: 10.1038/nrm3434

127. Taghavi N, Bagheri S, Akbarzadeh A. Prognostic implication of CD57, CD16, and TGF- $\beta$ expression in oral squamous cell carcinoma. J Oral Pathol Med. (2016) 45:58-62. doi: 10.1111/jop.12320

128. Takahashi H, Sakakura K, Kudo T, Toyoda M, Kaira K, Oyama $\mathrm{T}$, et al. Cancer-associated fibroblasts promote an immunosuppressive microenvironment through the induction and accumulation of protumoral macrophages. Oncotarget. (2017) 8:8633-47. doi: 10.18632/oncotarget.14374

129. Walsh JE, Young MR. TGF-beta regulation of focal adhesion proteins and motility of premalignant oral lesions via protein phosphatase 1. Anticancer Res. (2011) 31:3159-64.

130. Yoshimatsu Y, Wakabayashi I, Kimuro S, Takahashi N, Takahashi K, Kobayashi M, et al. TNF- $\alpha$ enhances TGF- $\beta$-induced endothelial-tomesenchymal transition via TGF- $\beta$ signal augmentation. Cancer Sci. (2020) 111:2385-99. doi: 10.1111/cas.14455

131. Ruff M, Leyme A, Le Cann F, Bonnier D, Le Seyec J, Chesnel F, et al. The disintegrin and metalloprotease ADAM12 is associated with TGF- $\beta$-induced epithelial to mesenchymal transition. PLoS ONE. (2015) 10:e0139179. doi: 10.1371/journal.pone.0139179

132. Terabe M, Park JM, Berzofsky JA. Role of IL-13 in regulation of antitumor immunity and tumor growth. Cancer Immunol Immunother. (2004) 53:79-85. doi: 10.1007/s00262-003-0445-0

133. Lallemant B, Evrard A, Combescure C, Chapuis H, Chambon G, Raynal C, et al. Clinical relevance of nine transcriptional molecular markers for the diagnosis of head and neck squamous cell carcinoma in tissue and saliva rinse. BMC Cancer. (2009) 9:370. doi: 10.1186/1471-2407-9-370

134. Koike H, Uzawa K, Nakashima D, Shimada K, Kato Y, Higo M, et al. Identification of differentially expressed proteins in oral squamous cell carcinoma using a global proteomic approach. Int J Oncol. (2005) 27:5967. doi: $10.3892 /$ ijo.27.1.59

135. Sun Y, Liu N, Guan X, Wu H, Sun Z, Zeng H. Immunosuppression Induced by Chronic Inflammation and the Progression to Oral Squamous Cell Carcinoma. Mediators Inflamm. (2016) 2016:5715719. doi: 10.1155/2016/5715719

136. Chen CJ, Sung WW, Su TC, Chen MK, Wu PR, Yeh KT, et al. High expression of interleukin 10 might predict poor prognosis in early stage oral squamous cell carcinoma patients. Clin Chim Acta. (2013) 415:2530. doi: $10.1016 /$ j.cca.2012.09.009

137. Fallon PG, Jolin HE, Smith P, Emson CL, Townsend MJ, Fallon $\mathrm{R}$, et al. IL-4 induces characteristic Th2 responses even in the combined absence of IL-5, IL-9, and IL-13. Immunity. (2002) 17:7-17. doi: 10.1016/S1074-7613(02)00332-1

138. Terabe M, Matsui S, Noben-Trauth N, Chen H, Watson C, Donaldson $\mathrm{DD}$, et al. NKT cell-mediated repression of tumor immunosurveillance by IL-13 and the IL-4R-STAT6 pathway. Nat Immunol. (2000) 1:51520. doi: $10.1038 / 82771$

139. D'Arcangelo E, Wu NC, Cadavid JL, McGuigan AP. The life cycle of cancerassociated fibroblasts within the tumour stroma and its importance in disease outcome. Br J Cancer. (2020) 122:931-42. doi: 10.1038/s41416-019-0705-1

140. Puram SV, Tirosh I, Parikh AS, Patel AP, Yizhak K, Gillespie S, et al. Single-cell transcriptomic analysis of primary and metastatic tumor ecosystems in head and neck cancer. Cell. (2017) 171:161124.e1624. doi: 10.1016/j.cell.2017.10.044

141. Rhodus NL, Ho V, Miller CS, Myers S, Ondrey F. NF-kappaB dependent cytokine levels in saliva of patients with oral preneoplastic lesions 
and oral squamous cell carcinoma. Cancer Detect Prev. (2005) 29:425. doi: 10.1016/j.cdp.2004.10.003

142. Haque A, Moriyama M, Kubota K, Ishiguro N, Sakamoto M, Chinju A, et al. CD206(+) tumor-associated macrophages promote proliferation and invasion in oral squamous cell carcinoma via EGF production. Sci Rep. (2019) 9:14611. doi: 10.1038/s41598-019-51149-1

143. Lee CH, Liu SY, Chou KC, Yeh CT, Shiah SG, Huang RY, et al. Tumor-associated macrophages promote oral cancer progression through activation of the Axl signaling pathway. Ann Surg Oncol. (2014) 21:10317. doi: $10.1245 / \mathrm{s} 10434-013-3400-0$

144. Hu Y, He MY, Zhu LF, Yang CC, Zhou ML, Wang Q, et al. Tumorassociated macrophages correlate with the clinicopathological features and poor outcomes via inducing epithelial to mesenchymal transition in oral squamous cell carcinoma. J Exp Clin Cancer Res. (2016) 35:12. doi: 10.1186/s13046-015-0281-z

145. Greten FR, Grivennikov SI. Inflammation and cancer: triggers, mechanisms, and consequences. Immunity. (2019) 51:2741. doi: 10.1016/j.immuni.2019.06.025

146. Michailidou EZ, Markopoulos AK, Antoniades DZ. VEGF expression from human dysplastic or malignant oral epithelium may be related to mast cell density and the subsequent angiogenetic phenomena. Int J Oral Maxillofac Surg. (2012) 41:1467-73. doi: 10.1016/j.ijom.2011.12.038

147. López de Cicco R, Watson JC, Bassi DE, Litwin S, Klein-Szanto AJ. Simultaneous expression of furin and vascular endothelial growth factor in human oral tongue squamous cell carcinoma progression. Clin Cancer Res. (2004) 10:4480-8. doi: 10.1158/1078-0432.CCR-03-0670

148. Prime SS, Cirillo N, Hassona Y, Lambert DW, Paterson IC, Mellone M, et al. Fibroblast activation and senescence in oral cancer. J Oral Pathol Med. (2017) 46:82-8. doi: 10.1111 /jop. 12456

149. Dourado MR, Guerra ENS, Salo T, Lambert DW, Coletta RD. Prognostic value of the immunohistochemical detection of cancer-associated fibroblasts in oral cancer: a systematic review and meta-analysis. J Oral Pathol Med. (2018) 47:443-53. doi: 10.1111/jop.12623

150. Elmusrati AA, Pilborough AE, Khurram SA, Lambert DW. Cancerassociated fibroblasts promote bone invasion in oral squamous cell carcinoma. Br J Cancer. (2017) 117:867-75. doi: 10.1038/bjc. 2017.239

151. Davalos AR, Coppe JP, Campisi J, Desprez PY. Senescent cells as a source of inflammatory factors for tumor progression. Cancer Metastasis Rev. (2010) 29:273-83. doi: 10.1007/s10555-010-9220-9

152. Niklander S, Bandaru D, Lambert DW, Hunter KD. ROCK inhibition modulates the senescence-associated secretory phenotype (SASP) in oral keratinocytes. FEBS Open Bio. (2020) 10:2740-9. doi: 10.1002/2211-5463.13012

153. Faget DV, Ren Q, Stewart SA. Unmasking senescence: contextdependent effects of SASP in cancer. Nat Rev Cancer. (2019) 19:439-53. doi: 10.1038/s41568-019-0156-2

154. Lau L, Porciuncula A, Yu A, Iwakura Y, David G. Uncoupling the senescenceassociated secretory phenotype from cell cycle exit via interleukin1 inactivation unveils its protumorigenic role. Mol Cell Biol. (2019) 39:e00586. doi: 10.1128/MCB.00586-18

155. Velarde MC, Demaria M, Campisi J. Senescent cells and their secretory phenotype as targets for cancer therapy. Interdiscip Top Gerontol. (2013) 38:17-27. doi: $10.1159 / 000343572$
156. Pezelj-Ribaric S, Prso IB, Abram M, Glazar I, Brumini G, Simunovic-Soskic M. Salivary levels of tumor necrosis factor-alpha in oral lichen planus. Mediators Inflamm. (2004) 13:131-3. doi: 10.1080/09629350410001688530

157. Ghallab NA, el-Wakeel N, Shaker OG. Levels of salivary IFN-gamma, TNFalfa, and TNF receptor-2 as prognostic markers in (erosive) oral lichen planus. Mediators Inflamm. (2010) 2010:847632. doi: 10.1155/2010/847632

158. Kaur J, Jacobs R. Proinflammatory cytokine levels in oral lichen planus, oral leukoplakia, and oral submucous fibrosis. J Korean Assoc Oral Maxillofac Surg. (2015) 41:171-5. doi: 10.5125/jkaoms.2015.41.4.171

159. Juretić M, Cerović R, Belušić-Gobić M, Brekalo Pršo I, Kqiku L, Špalj S, et al. Salivary levels of TNF- $\alpha$ and IL-6 in patients with oral premalignant and malignant lesions. Folia Biol. (2013) 59:99-102.

160. Singh P, Verma JK, Singh JK. Validation of salivary markers, IL-1 $\beta$, IL-8 and Lgals3bp for detection of oral squamous cell carcinoma in an Indian population. Sci Rep. (2020) 10:7365. doi: 10.1038/s41598-020-64494-3

161. Li Y, St John MA, Zhou X, Kim Y, Sinha U, Jordan RC, et al. Salivary transcriptome diagnostics for oral cancer detection. Clin Cancer Res. (2004) 10:8442-50. doi: 10.1158/1078-0432.CCR-04-1167

162. Bagan L, Sáez GT, Tormos MC, Labaig-Rueda C, MurilloCortes J, Bagan JV. Salivary and serum interleukin-6 levels in proliferative verrucous leukoplakia. Clin Oral Investig. (2016) 20:737-43. doi: 10.1007/s00784-015-1551-z

163. Dineshkumar T, Ashwini BK, Rameshkumar A, Rajashree P, Ramya R, Rajkumar K. Salivary and serum interleukin-6 levels in oral premalignant disorders and squamous cell carcinoma: diagnostic value and clinicopathologic correlations. Asian Pac J Cancer Prev. (2016) 17:4899-906. doi: 10.22034/APJCP.2016.17.11.4899

164. Khyani IAM, Qureshi MA, Mirza T, Farooq MU. Detection of interleukins-6 and 8 in saliva as potential biomarkers of oral pre-malignant lesion and oral carcinoma: a breakthrough in salivary diagnostics in Pakistan. Pak J Pharm Sci. (2017) 30:817-23.

165. Val M, Sidoti Pinto GA, Manini L, Gandolfo S, Pentenero M. Variations of salivary concentration of cytokines and chemokines in presence of oral squamous cell carcinoma. A case-crossover longitudinal prospective study. Cytokine. (2019) 120:62-5. doi: 10.1016/j.cyto.2019.04.009

166. Brinkmann O, Kastratovic DA, Dimitrijevic MV, Konstantinovic VS, Jelovac DB, Antic J, et al. Oral squamous cell carcinoma detection by salivary biomarkers in a Serbian population. Oral Oncol. (2011) 47:515. doi: 10.1016/j.oraloncology.2010.10.009

167. St John MA, Li Y, Zhou X, Denny P, Ho CM, Montemagno C, et al. Interleukin 6 and interleukin 8 as potential biomarkers for oral cavity and oropharyngeal squamous cell carcinoma. Arch Otolaryngol Head Neck Surg. (2004) 130:929-35. doi: 10.1001/archotol.130.8.929

Conflict of Interest: The author declares that the research was conducted in the absence of any commercial or financial relationships that could be construed as a potential conflict of interest.

Copyright $\odot 2021$ Niklander. This is an open-access article distributed under the terms of the Creative Commons Attribution License (CC BY). The use, distribution or reproduction in other forums is permitted, provided the original author(s) and the copyright owner(s) are credited and that the original publication in this journal is cited, in accordance with accepted academic practice. No use, distribution or reproduction is permitted which does not comply with these terms. 